\title{
Corruption and Insecurity in Nigeria
}

\author{
Musa Idris ${ }^{1}$ \\ ${ }^{1}$ Department of Public Administration, Faculty of Administration, Ahmadu Bello University, Zaria, Nigeria \\ Correspondence: Musa Idris, Department of Public Administration, Faculty of Administration, Ahmadu Bello \\ University, Zaria, Nigeria. Tel: 803-477-2717. E-mail: idi_musa_2009@yahoo.com
}

$\begin{array}{lc}\text { Received: January 25, } 2013 & \text { Accepted: February 1, } 2013 \quad \text { Online Published: April 24, } 2013 \\ \text { doi:10.5539/par.v2n1p59 } & \text { URL: http://dx.doi.org/10.5539/par.v2n1p59 }\end{array}$

\begin{abstract}
The increasing incidence of the twin evils of corruption and insecurity in Nigeria in spite of efforts made by successive administrations aimed at reducing their tide have been issues of public concern. The major objective of this paper is to identify the causes of corruption and insecurity in Nigeria between $2001-2010$ and examine the relationship between the two. The research design is content analyses of secondary data from Transparency International for corruption and the Mo Ibrahim Foundation for data on insecurity. The data has been presented in tables and analysed using percentages and averages. The Spearman's Rank Correlation Coefficient was used in testing the hypothesis postulated. The major cause of insecurity in Nigeria is corruption and failure of governance to achieve the Fundamental Objectives and Directive Principles of State Policy as contained in the Constitution of the Federal Republic of Nigeria. Others are greed by insurgent groups and the proliferation of weapons. The study revealed that there exist a perfect correlation between corruption and insecurity in Nigeria and that greed by insurgent groups and corruption by public officials caused deprivation, alienation, conflict and insecurity in Nigeria. The study recommends for improvement in the quality of governance in order to reduce the incidence of corruption and insecurity in Nigeria.
\end{abstract}

Keywords: corruption, insecurity

\section{Introduction}

\subsection{Background to the Study and Statement of the Problem}

The increasing incidence of the twin evils of corruption and insecurity in Nigeria pose great challenge to governance and have thus, become issues of public concern. Chapter II of the Constitution of the Federal Republic of Nigeria 1999, pertaining to the Fundamental Objectives and Directive Principles of State Policy in Section 2(b) specifically provides that "the security and welfare of the people shall be the primary purpose of government." Similarly, section 15 (5) of the constitution provides that "the state shall abolish all corrupt practices and abuse of power." Pursuant to this, successive administrations in Nigeria made concerted efforts to reform the security sector (Fayeye, 2007; National Planning Commission (NPC), 2004; Zebadi, 2007). In recent years, the sector has also been receiving a lion-share of our national budget. Laws have also been enacted and institutions established to fight corruption. These include the Independent Corrupt Practices and Other Related Offences Commission (ICPC) established through the ICPC Act, 2000 and the Economic and Financial Crimes Commission (EFCC) vide the EFCC Act, 2004. Others are the Fiscal Responsibility Commission established vide Fiscal Responsibility Act, 2007, the Bureau for Public Procurement established through the Public Procurement Act, 2007 and the Nigeria Extractive Industries Transparency Initiative (NEITI) through the NEITI Act, 2007.

In spite of all these efforts, corruption is still manifested in different sectors of governance in Nigeria. For instance, prior to the establishment of the above mentioned anti-corruption agencies and return to democratic governance to Nigeria, Costa (2008), the United Nations Executive Director for Drugs, Narcotics and Money Laundering estimates that corrupt leaders in embezzled close to $\$ 400$ billion within $1966-1999$. With the return to democratic governance to Nigeria in 1999 and establishment of many anti-corruption agencies Shehu (2011) citing a research conducted by the Human Rights Watch in 2007 estimated that during the eight year period of Obasanjo Administration, Nigeria lost between US\$4 billion and US\$8 billion annually to corruption. Between 2005 and 2007 alone, state Governors and politicians, allegedly embezzled US\$250 billion hidden in Western banks and other offshore financial centres (Shehu, 2011). Others include the Siemens 1.3 billion euro and 
Wilbrow International's 10 million euro bribery scandals involving some Federal Public servants and Foreign Firms between 2006 and 2007 (Akinrijomu, 2009; Financial Standard, 2007) Transparency International's Corruption Perceptions Index (CPI) for Nigeria varies from the lowest of 1.0 in 2001 to the highest of 2.7 out of 10.0 in 2008. This was neither maintained nor improved upon as the CPI slipped back to 2.5 in 2009 and further to 2.4 in 2010 .

The alarming rate of insecurity is not less disturbing in spite of the reforms undertaken and substantial share of national budgets allocated to the security sector. There have been serious and continuous threats to national and individual security in the form of organized crimes, election related violence, and violent extremism, including oil bunkering and kidnapping initially associated with the Niger-Delta Crisis but which later spread to the other parts of the country following the amnesty deal in 2009. There have also been alarming incidences of armed robbery, car snatching and ritual killings. The most recent instances are the post-election violence which broke out across many of the northern states and the fearsome insurgence of the deadly "Boko-Haram" in northern Nigeria especially the North-East (Shehu, 2011). Why is the rate of corruption and insecurity high in Nigeria in spite of the efforts made to fighting the twin-evils. What are the causes of corruption and insecurity in Nigeria? Is there any relationship between corruption and insecurity in Nigeria? How can the incidence of corruption and insecurity be reduced in Nigeria?

\subsection{Objectives, Hypothesis and Significance of the Study}

The objectives of this study are to identify the causes of corruption and insecurity in Nigeria and examine the relationship between the two variables between 2001 - 2010. Recommendations will also be made on how to reduce the incidence of corruption and insecurity in Nigeria in view of the finding made. The Null Hypothesis postulated for the study states that, there is no significant relationship between corruption and insecurity in Nigeria. Transparency International's CPI for the period under study $(2001-2010)$ indicates that corruption is more pervasive in countries with high rate of insecurity; Somalia, Bangladesh, Iraq, Sudan, Chad, Angola and Congo Democratic Republic among others. The Mo Ibrahim Index of African Governance $(2001-2010)$ has also shown that countries with high rate of insecurity (Somalia, Sudan, and Nigeria etc) also have high rate of corruption. Similarly, Shehu (2007) attempted to correlate corruption with conflict in Nigeria. All these studies were theoretical rather than empirical. It is this knowledge gap that this study attempts to cover by determining whether or not an empirical relationship exists between corruption and insecurity in Nigeria.

\subsection{Scope and Limitations of the Study}

The study spans for a decade $(2001-2010)$. This has been determined by the availability of secondary data derived especially from the Mo Ibrahim Foundation. The study also has a national coverage for maximum utility. Insecurity in the study is at both personal and national levels as the two are mutually exclusive. It is also concerned with public sector corruption without undervaluing the occurrence of the vice in the private sector. The study also acknowledges collusion of the public and private sectors in corruption. However, public sector corruption is of greater concern to governmental studies. The major limitation of the study is that data on security as obtained from the Mo Ibrahim Index of African Governance is captured as "safety and rule of law." This consist of rule of law, accountability, personal safety and national security sub-components. This is however, not enough to invalidate the findings of the study as the sub-components are interrelated.

\section{Materials Studied}

\subsection{The Concept of Corruption}

Corruption as a concept is difficult to define with precision. Scholars and organisations alike therefore, advanced different definitions based on their orientation. Svensson (2005), Tanzi (1998) and Transparency International (TI 2003 and 2009) define corruption as the abuse or misuse of public office or power for private gain or benefit. Ocheje (2001) from a legal perspective observes that official corruption refers to deviation from the duties or rules of public service. He adds that is easier to identify what corruption is not, as opposed to what corruption is because of the forms in which corruption manifests itself. The definitions advanced by Svensson (2005), Tanzi $(1998,564)$ and TI, define corruption as it relates to the public sector alone as if it does not occur in the private sector. This however, fits our study. But, it is worthy to note that corruption is not only undertaken for personal or self gain, as it can also be undertaken for the benefit of a third party or both.

Ocheje's $(2001,179)$ assertion that it is easier to identify what corruption is not rather than what it is runs counter to the view of Akinyemi (2010). Akinyemi (2010) argues that corruption can be better understood by identifying its constituent elements. These elements are bribery, trading in influence, graft and patronage. Others are nepotism and cronyism, electoral and vote fraud, embezzlement, kickbacks and involvement in organised 
crimes. It also include unholy alliance and what he called "quiet corruption" meaning citizens not receiving services for which public officials have been paid to deliver. This operational definition better explains corruption than the conceptual definitions earlier advanced.

\subsection{The Cause of Corruption}

The causes of corruption are many and varied. Svensson (2005) in an empirical study of the most corrupt countries in the world including Nigeria using TI 2003 CPI established that a strong relationship exist between income and corruption. Others are corruption and human development and government regulation of the market and inadequate media freedom. Tanzi (1998) in a similar study identified the causes of corruption in public sector to include, excessive government regulation of the market and authorisations. It also include spending decisions such as provision of goods below market price like the subsidies on petroleum products and extra budgetary accounts like the excess crude account in Nigeria. Others are political party financing, level of public sector wages and penalty system.

The African Development Bank (ADB) Group (2006) asserts that corrupt practices become the exception rather than the norm if the likelihood of being caught is high, if the consequences once caught is predictable and severe, and if it is generally condemned by the society. The bank summarises the dynamics of public sector corruption with a simple model thus;

$$
\mathrm{C}=\mathrm{M}+\mathrm{D}-\mathrm{A}
$$

where Corruption $=$ Monopoly + Discretion - Accountability. Under this model, a public official is assumed to have monopoly power over a good or service which generates economic rent such as the petroleum sector in Nigeria. It is also assumed that the public official has the discretion to decide who will acquire it and is not accountable for his action. Thus, corruption thrives where there is government monopoly, regulation of the economy, and where public accountability is lacking.

Similarly Huther and Sha (2000, 2 - 4) argues that corrupt practices become attractive when the expected gains exceed the expected costs of undertaking the act. Therefore, a self interested individual will seek out or accept corruption if the expected gains outweigh the costs. That is Where $\mathrm{E}$ is the expected gains operator

$$
\mathrm{E}[\mathrm{B}]=\mathrm{n} \times \mathrm{E}[\mathrm{G}]-\operatorname{Prob}(\mathrm{P}) \times \mathrm{P}>0
$$

$\mathrm{n}$ is the number of corrupt transactions

$\mathrm{G}$ is the gain from the corrupt transaction

Prob (P) is the probability of paying a penalty

$\mathrm{P}$ is the penalty for the corrupt activity.

This equation indicates that corruption becomes pervasive when the expected gains are greater than zero because, the government is involved in many transactions and regulations from which corrupt public officials gain. In addition, the probability of being caught is narrow because of week institutions and even when caught the penalty is not severe to serve as a deterrent. A typical example of this scenario is the case of Bode George and the Thirty one state governors between 1999 - 2007 were alleged to be corrupt (Buhari, 2007) but only the former Bayelsa State Governor (DSP Alarmiesiegha) was convicted. From the literature reviewed, the causes of public sector corruption include government monopoly and excessive regulation of the economy, extra budgetary accounts, poor public sector wages and secrecy in government business. Others are weak institutional controls and weak and mild penalty system to deter corruption.

\subsection{The Concept of Insecurity}

To have a good understanding of what insecurity is, it is important to know what security is all about. Although, the provision of security to the lives and property of the citizenry is the primary purpose of the state (Mazrui \& Mazrui, 1997) security is difficult to define with precision. Zebadi (2007) observes that the concept of security has always been associated with the safety and survival of the state and its citizens from harm or destruction. He further explains that security is not limited to the preparedness of the defense and security forces while subsuming the safety of the citizens to the state. It is in view of this that Fayeye (2007) asserts that security of a nation requires moving away form the traditional militaristic and state - centric definition of security towards human security. To him, security encompasses the personal and communal state of being secured from a wide range of critical and pervasive threats. Concomitant to this, Nnoli (2006) sees national security as a cherished value associated with physical safety of individuals, groups and nation states. In an objective sense, it denotes safety from threats, anxiety and danger. It is also subjective and psychological to the extent that it can be measured by the absence of fear that threat, anxiety or danger will occur. Security is thus, physical and 
psychological, objective and subjective as well as multi-dimensional; social, economic, political and environmental (Zebadi, 2007).

\subsection{Causes of Insecurity}

The Mo Ibrahim Foundation ( $2009 \& 2011)$ offers an operational definition of security at individual and national levels. At the level of an individual, security encompasses safety from domestic political persecution, social unrest and safety of the person. Others are freedom from violent crimes and human trafficking. At the national level, security means safety from cross-border tensions, government involvement in armed conflict and the extent of domestic armed conflict. It is also concerned with the number of political refugees and internally displaced people. From the foregoing definitions, insecurity denotes prevalence of physical and or potential threat of fear, anxiety or danger detrimental to the safety and survival of individuals, groups and the state at large. This can be economic, social, political and environmental. In Nigeria, this comprises of the rising incidence of armed robbery, kidnapping, militancy in the Niger Delta, the insurgence of the dreaded Boko Haram in northern Nigeria, electoral violence, communal clashes, ritual killings and oil bunkering among others.

The causes of insecurity are many and varied. These include the proliferation of arms from war-turn countries, local manufacturers and multi-national corporations (Okiro, n. d.). Bujra (2004) identified that the multi-ethnic character of most African states makes conflict more likely often leading to politicization of ethnicity, the distortion in the political economy of Africa and the activities of international arms merchants. Others are competition for scarce resources such as the extraction of oil in the Niger Delta and the resultant environmental degradation. The International Firearm Prevention and Policy estimates the increasing numbering of gun-deaths and injury in Nigeria from 1,255 in 2000 to 2,120 in 2001 and 2,550 in 2004 (Tell Magazine, 2012). Similarly, the large quantity of sophisticated arms and ammunition surrendered by Niger Delta Militants in the amnesty programme indicates the alarming rate of these weapons in the country and its security implications for the country (Tell Magazine, 2009).

\subsection{Relationship between Corruption and Insecurity}

Although, both Okiro (nd) and Bujra (2004) attribute the proliferation of arms and ammunition as one of the major causes of insecurity in Nigeria, it is noteworthy to state that corruption in Nigeria is both criminal and monopolistic. Literature suggests that corruption reproduces greed and creates incentives for unregulated competition for resources and power. It also undermines the capacity of Nigeria to mitigate normal social conflict and create avenues for redressing injustice as with the Boko Haram (Shehu, 2011). Shehu (2011) citing the UNDP 2006 Human Development report on the Niger Delta gives a graphic picture of how corruption in Nigeria intensifies desperate conditions of socio-economic exclusion as the cause of youth restiveness in the region. Corruption in the security sector particularly has diminished the capacity of the Nigerian state to maintain effective law and order across the country in the mist of violent crimes as the Nigeria police was rated the most corrupt public institution in the country (FRN, 2003).

\subsection{Theoretical Framework}

The Greed and Grievance Theories will be used as framework for the paper. The theories were crystalised and popularized by Collier and Hoeffler (2002) in their write-up "Great and Grievance in Civil War. They were used by Murshed and Tadjoeddin (nd) in "Revisiting the Greed and Grievance Explanations for Violent Internal Conflict." Greed represents elite competition over valuable natural resource rents. Greedy behaviour of insurgent groups in organising insurgence against the government can be motivated by opportunities. These are financing, recruiting and geography. Grievance theory or justice seeking motivation on the other hand argues that conflict can arise as a result of relative deprivation, polarisation and horizontal inequality.

In relation to this study "Greed" represents the activities of those organisations causing insecurity such as the Niger-Delta militants, Boko - Haram insurgents, politicians, and kidnappers among others. These organisations use violent means in fighting the government for their interest. Their activities are facilitated by finances from abroad and or within the country. Recruitment which is about the opportunity to induct fighting manpower is also made easier by the high rate of youth unemployment, endemic poverty and poor education. Grievance can be caused by the discrepancy between what Nigerians think they deserve as contained in the constitution in the Federal Republic of Nigeria and what they actually believe they can get. For instance educational achievements may raise the aspiration of young people, but they become frustrated if unemployed and deprived - occasionally venting their anger in mass political violence. Corruption creates deprivation in the form of unemployment, poverty disparities and poor service delivery. Corruption in this study is an act of greed its effects cause deprivation, alienation, inequalities and grievances leading to conflict and insecurity. 


\section{Methods}

The research design for this study is content analyses of data obtained from Transparency International and the Mo Ibrahim Foundation. Transparency International is an international non-governmental anti-corruption watch-dog. The organisation uses Corruption Perceptions Index (CPI) to reflect the perceived levels of corruption in the public sector. The CPI gathers data from sources that span the last three years and ranges from between ten (highly clean) and zero (highly corrupt). This implies that, the closer a country's CPI is to ten (10) the more transparent the country is. Conversely, the closer a country's CPI is to zero (0), the more corrupt the country is. Transparency International uses the perception of knowledgeable respondents, local and expatriate residents, business elites, scholars and country analysis in arriving at the CPI. The CPI is a better measure of the level of corruption than the country's ranking. The ranking only shows a country's position among others and not the level of (TI 2002).

The Mo Ibrahim Foundation is a reputable non-governmental and African-Centered concerned with promoting and rewarding good governance in Africa. The organisation's Ibrahim Index of African Governance is relevant, up to date and one of the most reliable index of African Governance. One of the components used by the foundation is safety and rule of law which is measured in percentages. The data obtained from the two organisations will be presented in tables and analysed using averages and percentages. The Spearman's Rank Correlation Coefficient is used in testing the hypotheses postulated in section one with the aid of Statistical Package for Social Sciences (SPSS) at 95\% level of significance that is $5 \%(.0 .05 \%)$ margin of error.

\section{Results and Discussion}

The independent and dependent variables as contained in the hypothesis are corruption and insecurity respectively. Data on these variables as obtained from and Mo Ibrahim Foundation from $2001-2010$ are presented and analysed in tables 1 and 2 .

\subsection{The Level of Corruption in Nigeria}

Transparency International CPI represents the rate of transparency in the public sector. It ranges from $0-10$ which for the purpose of this study, is converted to percentages. The percentages of the CPIs are also deducted from 100 to arrive at the percentages on the level of corruption in Nigeria as presented in table 1.

Table 1. Transparency international corruption perception index and ranking for Nigeria $2001-2010$

\begin{tabular}{llllllll}
\hline Year & CPI & Transparency (\%) & $\begin{array}{l}\text { No. } \\
\text { Countries } \\
\text { Covered }\end{array}$ & of & Ranking & Corruption (\%) & Ranking \\
\hline 2001 & 1.0 & 10 & 91 & 90 & 90 & 2 \\
2002 & 1.6 & 16 & 102 & 101 & 84 & 2 \\
2003 & 1.4 & 14 & 133 & 132 & 86 & 2 \\
2004 & 1.6 & 16 & 145 & 144 & 84 & 2 \\
2005 & 1.9 & 19 & 158 & 152 & 81 & 6 \\
2006 & 2.2 & 22 & 163 & 142 & 78 & 21 \\
2007 & 2.2 & 22 & 179 & 147 & 78 & 32 \\
2008 & 2.7 & 27 & 180 & 121 & 73 & 59 \\
2009 & 2.5 & 25 & 180 & 130 & 75 & 50 \\
2010 & 2.4 & 24 & 178 & 134 & 76 & 44 \\
\hline S0urce: Adap & & 178 & & \\
\hline
\end{tabular}

Source: Adapted from Transparency International Corruption Perceptions Index 2001 - 2010

The data in table 1 indicates that the level of corruption for the decade has been high. This range from $90 \%$ in 2001 to the lowest of $73 \%$ in 2008 , the average, rate of corruption for the period is $80.5 \%$ which is very high. Conversely, the country recorded poor scores in transparency. The highest score in transparency was $27 \%$ in 2008 and lowest in 2001 with only $10 \%$. This is a very poor performance in transparency. The country's ranking shows that Nigeria has been among the six most corrupt countries between $2001-2005$. Though the country's 
ranking improved from 2006 to 2010, it does not indicate a reduction in the level of corruption. It only shows that more corrupt countries were included in the survey.

\subsection{Rate of Insecurity in Nigeria}

The major components of insecurity are physical or potential threats to the personal safety of the citizens, the extent of social unrest, political persecution, violent crimes and human trafficking. It also include the extent of government involvement in armed conflicts, cross border tension, domestic armed conflicts and number of displaced people. The extent of insecurity among fifty three African countries is presented table 2 .

Table 2. Nigeria's scores and ranking in insecurity 2001/2010

\begin{tabular}{|c|c|c|c|c|}
\hline Year & $\begin{array}{l}\text { Score on } \\
\text { Security (\%) }\end{array}$ & Security Ranking & $\begin{array}{l}\text { Score on Insecurity } \\
(\%)\end{array}$ & $\begin{array}{l}\text { Insecurity } \\
\text { Ranking }\end{array}$ \\
\hline 2001 & 43 & 43 & 57 & 10 \\
\hline 2002 & 42 & 43 & 58 & 10 \\
\hline 2003 & 42 & 43 & 58 & 10 \\
\hline 2004 & 41 & 45 & 59 & 8 \\
\hline 2005 & 43 & 43 & 57 & 10 \\
\hline 2006 & 42 & 44 & 58 & 9 \\
\hline 2007 & 44 & 43 & 56 & 10 \\
\hline 2008 & 47 & 36 & 53 & 17 \\
\hline 2009 & 44 & - & 56 & - \\
\hline 2010 & 46 & 36 & 54 & 17 \\
\hline
\end{tabular}

Source: Adapted from Mo Ibrahim Foundation; Ibrahim Index of African Governance 2001 - 2010

Since the Mo Ibrahim Foundation presents only the country's scores on safety and security, Nigeria's scores and rankings in insecurity were arrived at by subtracting the later from the former. The ranking in insecurity is arrived at by subtracting Nigeria's ranking in safety and security from the total of fifty three countries covered by the survey. The data indicates higher scores and rankings in insecurity in Nigeria as compared to security scores and rankings. The rate of insecurity was highest in 2004 followed by 2002 and 2003. Nigeria was the eight $\left(8^{\text {th }}\right)$ most insecure country in Africa in 2004. The average rate of insecurity in Nigeria for the period 2001 -2010 is $56.6 \%$ as compared to $43.3 \%$ for security.

\subsection{Test of Hypothesis}

The hypothesis postulated for the paper states; there is no significance relationship between the rate of corruption and the level of insecurity in Nigeria. The independent variable is corruption while insecurity is the dependent variable. The Spearman's Rank Correlation Coefficient was used in testing the hypothesis at 5\% (0.05) margin of error. This was computed with the aid of SPSS whose products are presented in table 3.

Table 3. Symmetric measures

\begin{tabular}{llrr}
\hline & & Value & Asymp. Std. Error \\
\hline Interval by Interval & Pearson's Research & 1.000 & $.000^{\mathrm{b}}$ \\
Ordinal by Ordinal & Spearman Correlation & 1.000 & $.000^{\mathrm{b}}$ \\
N of Valid Cases & & 405 &
\end{tabular}

a. Not assuming the null hypothesis.

b. Based on normal approximation. 
The calculated value as indicated in table 3 is 1.00 (perfect correlation) while the critical value is 0.564 . The calculated value of 1.00 is greater than the critical value of 0.564 . Thus, the null hypothesis is rejected. This indicates that there is a significant relationship (perfect correlation) between corruption and insecurity in Nigeria between $2001-2010$.

\section{Conclusion and Recommendations}

That data in tables 1 and 2 indicate that both the rate of corruption and insecurity to be high in Nigeria between 2001-2010. From the hypothesis tested, it has been revealed that there exist a perfect correlation between corruption and insecurity in Nigeria. In other words, the high level of corruption in Nigeria is one of the factors responsible for the high level of insecurity in the country. In relation to the theoretical framework, both greed by insurgent groups and corruption by public servant are responsible for the grievances expressed by the citizens have a result of deprivation and alienation. In other words, both the greed and grievance perspectives are complementary. However, their views alone has not adequately addressed the twin problems of corruption and insecurity in Nigeria which can be blamed on government failure to comply with the Fundamental Objectives and Directive Principles of State Policy as contained in the Constitution of the Federal Republic of Nigeria, 1999.

In order to address these problems, the root causes of corruption in Nigeria as identified in the literature need to be addressed. In summary, the causes of corruption include government excessive regulation of the oil sector in the form of subsidy payment that has created rents in Nigeria and unaccounted extra-budgetary expenditure in the form of excess-crude receipts from the Federation Account. Others are ineffective accountability frameworks, non-transparency in governance, poor public sector wages and weak and non enforcement of penalties for corruption offences. The deregulation of the oil sector is expected to reduce the number of corruption transaction and rent-seeking. There is the need for the reform of the electoral system for more credible elections and responsible representation at the various levels of government. A more responsible legislature will ensure greater accountability. The entire machinery of government should be reformed. This should include increase in public sector wages and reduction in workforce. The security and judicial staff in addition require reorientation. There is the need for political will to implement the freedom of Information Act and strengthen the civil society for more transparency in governance. The same political will is also required in enforcing penalties deterrent enough to reduce incentives for corruption. These recommendations are expected to improve the quality of governance, reduce temptations for greed actions, in the form of insurgence, create better life for the citizens, reduce deprivation, inequality, alienation and insecurity in Nigeria. However, since there may be other factors responsible for the state of insecurity in Nigeria, further research is suggested on the effect of poverty on insecurity in Nigeria.

\section{References}

African Development Bank Group. (2006). Combating Corruption in Africa; Issues and Challenges. Concept Note Paper for the 2006 Annual Meetings. Ouagadougou, Burkina Faso.

Akinrijomu, B. (2009, March 9). Slipping Back into Old Times. Tell, p. 6.

Akinyemi, A. B. (2010). Fighting Corruption and Social Conflict to Achieve Development. Text of the lead lecture delivered at the $10^{\text {th }}$ Anniversary Celebration of Arewa Consultative Forum on Thursday April $29^{\text {th }}$ 2010, Kaduna.

Buhari, M. (2007, October). Quote Me. Zero Tolerance. Nigeria's Economic and Financial Crimes Commission, 2(1), 14.

Bujra, A. (2004). African Conflicts; their Causes and their Political and Social Environment. Development Policy Management Forum Occasional Paper, No. 4. Addis Ababa.

Collier, P., \& Hoeffler, A. (2002). Greed and Grievance in Civil War. Centre for the Study of African Economics CSAE WPS/2002-01, the World Bank.

Costa, A. M. (2008). Anti-Corruption Climate Change: It started in Nigeria. The Eagle Watch, a Quarterly Newsletter of the EFCC Training and Research Institute, 2(5), 7-10.

Economic and Financial Crimes Commission (Establishment) Act, Federal Government of Nigeria. (2004).

Fayeye, J. O. (2007). Reforming the Security Sector. In H. Saliu, E. Amali, \& R. Olawepo (Eds.), Nigeria's Reform Programme; Issues and Challenges (pp. 142-157). Ilorin: Faculty of Business and Social Sciences, University of Ilorin. 
Federal Republic of Nigeria. (1999). Constitution of the Federal Republic of Nigeria 1999. Lagos; Federal Government Press.

Federal Republic of Nigeria. (2003). Nigeria Governance and Corruption Survey Study; Analysis of Survey Results, Households, Enterprises and Public Officials, Final Report.

Financial Standard. (2007, November 19). Why Nigeria Must Probe the Wilbrows Exposure. p. 10.

Fiscal Responsibility Act, Federal Republic of Nigeria. (2007).

Huther, J. \& Shah, A. (2000). Anti-Corruption Policies and Programmes. Policy Research Working Paper 2501, the World Bank Operations and Evaluation Department, December.

Ibrahim Index of African Governance (2001 - 2010 Editions). Retrieved from www.moibrahim foudnation.org

Mazrui, A., \& Mazrui, A. A. (1997). Interaction between the State and the Nation in Africa's Experience, Four Decades of Independence. In E. Oyedele (Ed.), Africa National Unity, Stability and Development (pp. 33 51). Ibadan: Sibon Books Limited.

Mo Ibrahim Foundation. (2009). Ibrahim Index of African Governance Summary. Retrieved August 7, 2009, from from www.moibrahimfoundation.org

Mo Ibrahim Foundation. (2011). 2011 Ibrahim Index of African Governance Summary. Retrieved June 5, 2012, from www.moibrahimfoundation.org

Murshed, M. S., \& Tadjoeddin, M. Z. (n. d.). Revisiting the Greed and Grievance Explanations for Violent Internal Conflict.

National Planning Commission. (2004). Nigeria; National Economic Empowerment and Development Strategy. Abuja. National Planning Commission.

Nigeria Extractive Industries Transparency Initiatives (NEITI) Act, Federal Republic of Nigeria. (2007).

Nnoli, O. (2006). National Security in Africa, A Radical New Perspective. Enugu: Pan African Centre for Research on Peace and Conflict Resolution.

Ocheje, P. D. (2001). Law and social change; a socio-legal analysis of Nigeria's Corrupt Practices and other Related Offences Act, 2000. Journal of African Law, 45(2), 173-195. http://dx.doi.org/10.1017/S0221855301001687

Okiro, M. Proliferation of Illegal Arms and Ethno-Religious Violence in Nigeria. In crime in Nigeria.

Public Procurement Act, Federal Republic of Nigeria. (2007).

Shehu, A. (2011). Corruption and Conflict in Nigeria; Implications for Peace, Security and National Development. Presented at the Third Public Lecture of the Institute for Peace and Conflict Resolution, Ministry of Foreign Affairs, Abuja, Nigeria on $24^{\text {th }}$ November, 2011.

Svensson, J. (2005). Eight questions about Corruption. Journal of Economic Perspectives, 19(3), 19-42. http://dx.doi.org/10.1257/089533005774357860

Tanzi, V. (1998). Corruption around the World; Causes, Consequences, Scope and Cures. IMF Staff Paper, 45(4), 559 - 594. (JEL E62, H1, H3, K4, N4). http://dx.doi.org/10.2307/3867585

Tell Magazine. (2009, October 12). The Arms Time Bomb. Tell Magazine, p. 20.

Tell Magazine. (2012, May 14). The Wages of Evil. Tell Magazine, p. 42.

The Corrupt Practices and Other Related Offences Act, Federal Republic of Nigeria. (2004).

Transparency International. (2003). Transparency International Corruption Perceptions Index 2002. Retrieved August 28, 2003, from htt//www.transparency.org

Transparency International Corruption Perception Index (2001 - 2010 Editions). Retrieved from $\mathrm{http} / / \mathrm{www} \cdot$ transaprency.org

Zebadi, I. S. (2007). Security Sector Reforms. In H. Saliu, E. Amali, \& R. Olawepo (Eds), Nigeria's Reform Programme; Issues and Challenges (pp. 122-141). Ilorin: Faculty of Business and Social Sciences, University of Ilorin. 